\title{
Cattle Fattening Practices in West Hararghe: Potentials and Constraints of Beef Cattle Production in Oromia Regional State, Ethiopia
}

\author{
Bezahegn Abebe ${ }^{1}$ \\ 1 Department of Animal Science, College of Agriculture Oda Bultum University, Ethiopia \\ Correspondence: Bezahegn Abebe, Department of Animal Science, College of Agriculture Oda Bultum \\ University, Chiro, Ethiopia. Tel: 251-9138-93686. E-mail: bezahegn@gmail.com
}

Received: January 2, 2019

Accepted: February 16, 2019 Online Published: June 15, 2019

doi:10.5539/jas.v11n8p120

URL: https://doi.org/10.5539/jas.v11n8p120

\begin{abstract}
The present study was conducted to investigate the status of beef cattle production system, major available beef cattle feed, constraints, and challenges of cattle fattening in Gemechis, Mesela, Tulo and Oda Bultum District, Western Hararge Zone, Oromia National Regional State. To select the districts and individual cattle fatteners, purposive selection techniques were applied based on their potentiality and beef cattle ownership, respectively. Accordingly a total of 120 cattle fatteners were included and interviewed using pre tested structured questionnaire. In addition to semi-structured questionnaire, group discussions and key informant interviews were carried out to support the survey data. As the assessment result showed fattening length in highland regions was significantly $(\mathrm{p}<0.001)$ higher than those of midland regions with mean value of $5.0 \pm 0.18$ and $4.1 \pm 0.18$ respectively. Green feeds from maize and sorghum origin which includes thinning contributes a major role as livestock feed during wet season whereas crop residues (mainly maize and sorghum stover) in wet season and wheat bran 'frushika' are the dominant feed resources supplement for cattle fatteners in the study area. Feed shortage and marketing of fattened animals were major constraints reported by the farmers. Beef marketing constraints prioritized by the respondents in the study area included problems created by brokers $(77.5 \%)$, seasonality of market price variation $(14.17 \%)$, low market price $(0.83 \%)$ and others $(7.5 \%)$. It can be concluded that cattle fattening could be one potential strategy to improve the income of the fatteners if utilizes seasonally available feed resources by improving utilization efficiency and controlled cattle marketing system by governmental bodies for sustainable market service, to protect the negative influence and interference of the broker's.
\end{abstract}

Keywords: cattle fattening, feed resources, marketing of live beef animals

\section{Introduction}

Cattle production in Ethiopia is an integral part of the mixed farming, agro-pastoral and pastoral production systems. At a national level, livestock is the source of industrial raw materials (milk, meat, hides and skin) and high value protein to potential consumers in Ethiopia (FAO, 2015). It also contributes about $45 \%$ to the Agricultural GDP, $18.7 \%$ to the national GDP and $16-19 \%$ to the total foreign exchange earnings of the country. The economic contribution of the livestock sub sector in Ethiopia is about $12 \%$ of the total GDP of the country and 33\% of agricultural Gross Domestic Product (GDP). In addition the sector also provides about $65 \%$ of the livelihood of the population (Ayele et al., 2003). Informally Ethiopia exports approximately 200,000 livestock annually (Yacob \& Catley, 2010). According to Asfawu et al. (2011), the country has been earning foreign currency by exporting meat and live animals namely cattle, sheep, camels and goats.

Ethiopia has one of the largest livestock population in Africa, which possess an estimated number of 52.13 million cattle, 24.2 million sheep, 22.6 million goats, 1.96 million horses, 6.4 million donkeys, 0.37 million mules, 0.99 million camels, 44.89 million poultry, and 4.99 million beehives (CSA, 2011). Ethiopia's commercial red meat (beef, mutton and goat) industry has made remarkable progress to date and shows considerable growth potential for the future. The government of Ethiopia encourages investments in meat processing, especially those that are focused on exporting value-added products abroad. A large chunk of this commercially-produced red meat, most of which is currently mutton and goat meat is largely going for export to 
the Middle East in order to generate foreign exchange. Beef exports are also growing, with additional market opportunities on the horizon (Shapiro et al., 2015).

In Ethiopia, there is limited information about their constraints, opportunities, challenges, economic efficiencies, production potentials and performances of beef animals under this sector (Bezahegn, 2014) and also particularly, the constraints, opportunities and challenges faced were not properly assessed despite the encouragement of the sector by government. Information about smallholder fattening or feedlot practices and its constraints is important for researchers, policy makers to take serious measures and suggest possible technologies to improve the productivity of the sector and hence maximize its contribution to the total Gross Domestic Product (GDP) or economy of the country. However, there is no adequate documented information on fattening practices of these smallholders' operators and their challenges in Ethiopia. Therefore, the major objective of this paper is designed to characterize and identify husbandry practice and major constraints marketing system of beef cattle production industries in the area.

\section{Materials and Methods}

\subsection{Description of Study Area}

The study was conducted in four districts of West Hararghe Zone (Gemechis, Oda Bultum, Tulo and Mesela) Oromia Regional State, Ethiopia. Zone of west Hararghe is located in Oromyia Region, and is characterized by a diversity of agro-climatic conditions which determine the composition of the rural economy.

In Western Hararghe zone, agriculture is the dominant economic activities mainly mixed type of farming where $55-65 \%$ of the livelihood is depend on food crops production, $12-15 \%$ livestock production, $10-15 \%$ cash crops (including fruits and vegetables) and 5\% pity trade. According to West Hararghe Zone Finance and Economic Development Office (2016), the zone is reported to have a total livestock population of 1,179,638 cattle, 181,959 sheep, 952,611 goats, 217,267 donkeys, 1,429,655 chicken and 82,587 bee hives that indicate high potential for livestock production

Gemechis is the one ofdistricts of West Hararghe. It is one of the fourteen districts in West Hararghe zone located at $343 \mathrm{~km}$ east of Addis Ababa and about $17 \mathrm{~km}$ south of Chiro, capital town of the zone. The district is found within 1300 to 2400 meters above sea level (m.a.s.l.). It receives an average annual rainfall of $850 \mathrm{~mm}$. The district has bi-modal distribution in nature with small rains starting from March/April to May and the main rainy season extending from June to September/October. The average temperature is $20^{\circ} \mathrm{C}$. The livestock populations of the district are 221711 cattle, 120000 goats, 30000 sheep, 250 horses, 1529 mules, 30000 donkeys, 8560 camels and 157,700 poultry (WHZLFDO, 2018).

Oda Bultum is located at $08054,3180 \mathrm{~N}, 0400,0210 \mathrm{E}$. Its Altitudinal range is from $1040-2500$ meters above sea level (m.a.s.l), the average altitude of the district is 1770 m.a.s.l. From the total land area/topography of the district; $60 \%$ is plain and $40 \%$ is steep slope. The annual rain fall is $900 \mathrm{~mm}-1100 \mathrm{~mm}$. The livestock populations of the district are 262,899 cattle, 96,220 goats, 23,234 sheep, 122,433 poultry, 47,322 donkeys, 1,873 horses and 1,620 mules, camel 19,324 (WHZLFDO, 2018).

Tulo is one of the districts in the Oromia Region of Ethiopia. Part of the Mirab Hararghe Zone, Tulo is bordered on the south by Mesela, on the west by Chiro, on the north by Doba, and on the east by the Misraq Hararghe Zone. Towns in Tulo include Debeso and Hirna. Coffee is an important cash crop of this woreda. Over 50 square kilometers are planted with this crop. The livestock populations of the district are 131,643 cattle, 77414 goats, 34,504 sheep, 212,441 poultry, 6,679 donkeys, 400 horses and 312 mules (WHZLFDO, 2018).

Mesela is one of the districts in the Oromia Region of Ethiopia. Part of the West Hararghe Zone, Mesela is bordered on the southwest by the Galetti River which separates it from Chiro, on the northwest by Tulo, and on the east by the East Hararghe Zone. Towns in Mesela include Goro Reye and Mesela. Coffee is an important cash crop of this woreda; over 50 square kilometers are planted with this crop .Coffee grown in Mesela is well known for its high quality. The 2007 national census reported a total population for this woreda of 151,698, of whom 76,864 were men and 74,834 were women; 4,590 or $3.03 \%$ of its population were urban dwellers.

\subsection{Sampling and Data Collection}

The study was carried out in highland (Mesela and Gemechis) and midland (Tulo and Oda Bultum) districts West Hararghe Oromia Regional State, Ethiopia. A total of 120 households that own beef cattle were randomly selected from the two agro-ecologies (highland and mid-land). Primary data was collected using pre tested semi-structured questionnaire through interview and discussion with the beef cattle owners. In addition, secondary information was gathered from literature and agricultural offices' reports. Physical observation of beef cattle farms was also be used as an instrument to collect data during the study. The collection of data for this 
study was largely supported by intensive interviews and focus group discussions of the sampled households, surveys and market observations in selected districts based on designed interview questionnaires. Data on the types of livestock species used for fattening, pattern of livestock preferences, market demand, chain of marketing, fattening cycle and duration, feed resources feeding procedure and constraints and housing of fattening cattle were collected from the beef cattle producers.

\subsection{Statistical Analysis}

Collected data was subjected to least squares analysis using descriptive statistics through the procedure of SAS statistical software to compare the available feed resources, cattle fattening practices, and constraints of fattening cattle between the two agro-ecology on beef cattle production operating systems. From the analysis of descriptive statistics and the ANOVA significant differences between the agro-ecology was compared using SAS statistical soft ware package. Index was calculated for question that requires ranking of the response according to the formula as employed by Musa et al. (2006).

\section{Results and Discussion}

\subsection{Experience of Fattening and Number of Animal per Fattening Cycle}

This study indicated that $(25.83 \%)$ of the farmers had long years of fattening experience $6-10$ years, but most of the farmers $(43.33 \%)$ had $3-5$ years and $(20 \%)$ of them have greater than 10 years but only $(10.83 \%)$ of the farmers have fattening experience of less than three years (Table 1). Evidence obtained from the present study revealed that most of the farmers $(58.33 \%)$ fatten one ox per cycle and $(30.83 \%)$ of them fatten two animals per cycle which means about (89\%) of the farmers fatten less than three animals per cycle. Moreover, $(9.17 \%)$ and $(1.67 \%)$ of the farmers had engaged in fattening with 3-5 and greater than five animals per cycle in the study area respectively. Therefore, this result indicated that most of the farmers in the study area fatten 1-2 head of cattle per cycle.

Table 1. Experience of farmers' involved in beef cattle fattening practices and number of animals fattened per cycle

\begin{tabular}{|c|c|c|c|c|c|}
\hline \multicolumn{3}{|c|}{ Fattening Experience } & \multicolumn{3}{|c|}{ Number of Animals/cycle } \\
\hline Variables & Fre. & $\%$ & Variables & Fre. & $\%$ \\
\hline Less than 3 years & 13 & 10.83 & One & 70 & 58.33 \\
\hline 3-5 years & 52 & 43.33 & Two & 37 & 30.83 \\
\hline $6-10$ years & 31 & 25.83 & Three to five & 11 & 9.17 \\
\hline Greater than 10 years & 24 & 20 & Greater than five & 2 & 1.67 \\
\hline Total $(\mathrm{N})$ & 120 & 100 & & 120 & 100 \\
\hline
\end{tabular}

Note. Fre. = Frequency, $\mathrm{N}=$ number of respondent.

\subsection{Duration of Fattening}

It was observed that the length of fattening period varies according to the type of agro-ecology. It indicated that, fattening length in highland regions was significantly $(p<0.001)$ higher than those of midland regions with mean value of $5.0 \pm 0.18$ and $4.1 \pm 0.18$ respectively. According to the farmers' perception, the long duration in the highland regions is due to slow body weight gain of fattening animals as a result of low feed offered because of less availability of feed and effect of cold environmental temperature. In addition to this, the reason of this can also be explained by the fact that animals in cold climate may be forced to utilize parts of the energy obtained from absorbed nutrients to cope up with cold weather rather than for body weight gain. Duration of 3 to 4 months of fattening length is also reported in commercial beef fattening farms (Tsegay \& Mengistu, 2013). 
Table 2. Least square means for length of fattening period, number of fattening cycle per year and number of animals fattened per cycle

\begin{tabular}{|c|c|c|c|c|}
\hline \multirow{2}{*}{ Variables } & \multirow{2}{*}{$\mathrm{N}$} & \multicolumn{3}{|c|}{ Least square means \pm standard error } \\
\hline & & Duration of fattening period (months) & Number of fattening cycle/yr & Number of animals/cycle \\
\hline Agro ecological zone & & 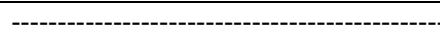 & ---- $\mathrm{LSM} \pm \mathrm{SE}$---------------- & 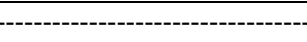 \\
\hline Highland & 60 & $5.0^{\mathrm{a}} \pm 0.18$ & $1.53^{\mathrm{a}} \pm 0.08$ & $1.43^{\mathrm{a}} \pm 0.09$ \\
\hline Mid-land & 60 & $4.1^{\mathrm{b}} \pm 0.15$ & $1.87^{\mathrm{b}} \pm 0.07$ & $1.85^{\mathrm{b}} \pm 0.16$ \\
\hline SL & & $* * *$ & $* *$ & $*$ \\
\hline
\end{tabular}

Note. ${ }^{\mathrm{a}},{ }^{\mathrm{b}}=$ means with different letter superscript across the column differ significantly; $\mathrm{SE}=$ standard error; $\mathrm{N}=$ Number of respondents; $* * *=$ significant at $(\mathrm{p}<0.001) ; * *=$ significant at $(\mathrm{p}<0.01) ; *=$ significant at $(\mathrm{p}<$ $0.05), \mathrm{NS}=$ not significant.

\subsection{Major Feed Resources and Season of Availablity}

As it is indicated in the table below (Table 3), the major sources of livestock feed in highland and mid-land of the study area were crop residues, grass hay, green feeds from crop lands, agro industrial byproducts and marginal grazing land. However, the importance and availability of feed resources indicated above is varied based on seasonal fluctuation. Accordingly, crop residues, agro-industrial by products (mainly wheat-bran), grass hay and stubble grazing are important feed resources during dry season whereas green feeds from crops like maize and sorghum origin, crop residues, weeds, crops thinning, and marginal lands for grazing or cut-carry feeding are principal feed resources. According to this study, crop residues (mainly maize and sorghum stover) are the dominant feed resources in both dry and wet season. This is due to the shortage of grazing land as a result of intensified utilization of land for crop cultivation which results scarcity of grassland for livestock feed production. Therefore, farmers are forced to use crop residues such as cereal straws, legume haulms, and maize and sorghum stovers as the main livestock feed resources in order to minimize the constraints of feed shortage. The results in the present study is supported by findings reported for the West Hararghe (Abdi et al., 2013) which indicated that feed from maize and sorghum origin plays a significant sources of livestock feed.

Table 3. Rank of major feed resources during dry and wet season

\begin{tabular}{|c|c|c|c|c|c|c|c|c|c|}
\hline \multirow{2}{*}{ Variables } & \multirow{2}{*}{ Season } & \multicolumn{6}{|c|}{ Weighted frequency } & \multirow{2}{*}{ Index } & \multirow{2}{*}{ Rank } \\
\hline & & 1 & 2 & 3 & 4 & 5 & 6 & & \\
\hline \multicolumn{10}{|l|}{ Highland $(N=60)$} \\
\hline Grazing land & Dry & - & - & 1 & 11 & 16 & 32 & 0.08 & 5 \\
\hline Crop residue & Dry & 42 & 18 & - & - & - & - & 0.28 & 1 \\
\hline Stubble grazing & Dry & - & 5 & 4 & 29 & 22 & - & 0.14 & 4 \\
\hline Grass hay & Dry & 6 & 13 & 34 & 2 & 5 & - & 0.20 & 3 \\
\hline Wheat bran & Dry & 14 & 25 & 16 & 5 & - & - & 0.23 & 2 \\
\hline Others & Dry & - & - & - & 5 & 26 & 28 & 0.08 & 5 \\
\hline Green maize \& Sorghum leaf & Wet & 29 & 13 & 12 & 3 & 2 & 1 & 0.26 & 1 \\
\hline Green weeds & Wet & 5 & 15 & 27 & 13 & - & - & 0.22 & 3 \\
\hline Green grasses & Wet & 7 & 14 & 16 & 23 & - & - & 0.21 & 4 \\
\hline Green maize stalk & Wet & 19 & 10 & 5 & 23 & 3 & - & 0.23 & 2 \\
\hline Other green feed & Wet & - & - & - & - & 34 & 26 & 0.08 & 5 \\
\hline \multicolumn{10}{|l|}{$\operatorname{Mid}$-land $(N=60)$} \\
\hline Grazing land & Dry & 1 & 1 & 1 & 7 & 16 & 34 & 0.08 & 5 \\
\hline Crop residue & Dry & 41 & 12 & 5 & 2 & - & - & 0.26 & 1 \\
\hline Stubble grazing & Dry & 3 & 16 & 19 & 17 & 5 & - & 0.19 & 3 \\
\hline Grass hay & Dry & 1 & 13 & 18 & 17 & 10 & 1 & 0.17 & 4 \\
\hline Wheat bran & Dry & 15 & 18 & 16 & 7 & 4 & - & 0.22 & 2 \\
\hline Others & Dry & - & - & - & 8 & 24 & 28 & 0.08 & 5 \\
\hline Green maize\& Sorghum leaf & Wet & 37 & 13 & 7 & 2 & - & 1 & 0.28 & 1 \\
\hline Green weeds & Wet & 9 & 20 & 28 & 3 & - & - & 0.24 & 3 \\
\hline Green grasses & Wet & 4 & 12 & 25 & 19 & - & - & 0.21 & 4 \\
\hline Green maize stalk & Wet & 9 & 13 & 4 & 32 & 2 & - & 0.20 & 2 \\
\hline Other green feed & Wet & - & - & - & 1 & 35 & 24 & 0.08 & 5 \\
\hline
\end{tabular}

Note. Others $=$ refer household leftover and industrial by-product supplement for dry season; tree leafs and industrial by products for wet season. 
The availability of sorghum stover is due to the fact that farmers grow sorghum as a sole crop and store sorghum stover for a long period, which is a common practice almost by all small farmers in the study area. The Farmers harvest and utilize green feed resources as livestock feeds like maize and sorghum thinning, leaf strips and stalks locally called 'Qaxara', green grassers from marginal land and also green weeds are feed resources for fattening animals under both highland and midland agro-ecology during wet season. This finding is also in line with the study reported by Fekadu and Alemu (2000) which indicated that leaf stripping from maize and sorghum plays a significant role in diets of fattening oxen in the eastern Hararghe highlands. In the study area, industrial by product from flower factory mainly wheat bran which is locally known as frushika is readily available on local market at a price and widely used by all farmers to supplement their animals. It is supplemented to fattening cattle after wetted with water and added salt in cut-barrels or wooden feed boxes. Some of the farmers also used linseed meal (Linum asitatissimum) and cottonseed cake as a protein supplement but they complain the high price of these supplement. In highland areas of the study areas the importance of stubble grazing is also not undermined which is common immediately after harvest time.

\subsection{Marketing System of Beef Animals}

Cattle fattening holds the major share of income sources for household heads in west Hararghe. This may be due to an increase in demand for beef as the result of increase in urbanization in the country as whole and emerging middle-class urban dwellers with higher income and more buying power that brings opportunities for beef cattle production. As a whole, in the study area cattle fatteners mainly fatten their oxen for the purpose of generating income and profit. Therefore, the farmers supply their fattened animals to the market using different marketing systems. As it is indicated in (Table 4) most respondents (60.83\%) take animals to local market place for selling, the rest $34.17 \%, 4.17 \%$, and $0.83 \%$ sell at farm gate to brokers, traders, and consumers respectively. Therefore most of the beef cattle producers taken their fattened animals to the market place for sale may be because of the inadequate information of the beef cattle market price. On the other hand, this indicated that without market price assessment by them, the farmers were not satisfied with the prices determined at their farm site.

Table 4. Marketing methods of fattening animals in percent

\begin{tabular}{lll}
\hline \multirow{2}{*}{ Beef cattle marketing methods } & \multicolumn{2}{c}{$\mathrm{N}=120$} \\
\cline { 2 - 3 } & Fre. & $\%$ \\
\hline Picked at farm gate by broker & 41 & 34.17 \\
Picked at fattening place by consumer & 1 & 0.83 \\
Taken to market place & 73 & 60.83 \\
Picked by trader at farm gate & 5 & 4.17 \\
Total & 120 & 100 \\
\hline
\end{tabular}

Note. $\mathrm{N}=$ number of respondent; Fre. $=$ Frequency.

\subsection{Market Information and Price Determination}

Market information is vital to minimize information gaps and uncertainties that exist in the agricultural sector. One of the characteristics of cattle markets in the study area is lack of transparency, which in turn makes it hard to know the actual price of a given animal. This is especially manifested by the diverse price sets imposed on the same type of live animal by different cattle traders and middlemen.

Coupled with the absence of official cattle price information system, the existing information exchange, which is based on personal relationships, leaves a huge gap in the case of market transparency. Moreover, the transparency issue is further compromised by other factors such as the difference in measuring systems (animals are transacted based on eye judgment, rather than weigh scales) and the special relationships between some farmers and trader. Under normal marketing system, buyers and sellers communicate mostly directly, and a seller tells the buyer his price range for the cattle he intends to sale. The buyer then negotiates with the seller and settles the price in secret. But if brokers are involved, a deal between the seller and buyer is closed and price will only be determined known to the buyer and the broker and kept secret from the seller. Therefore, as it is indicated in the (Table 5) below, the broker influences the market price of the cattle by favoring the buyers/traders which is the problems reported by the farmers in the study area.

According to the results of this study on market information sources, the majority of the respondents (45\%) reported that the initial price is set by the cattle owners in negotiation with the buyers. On the other hand, 
(34.17\%) of the farmers stated that the price of fattened cattle in the market will be set by the brokers which indicated that market price highly influenced by the middlemen. As most of the farmers explained the involvement of the brokers in marketing of their animals is a big problem which discourages the sector as these middlemen are not legally licensed and always do in favors of the traders. The purchase price will also determined by negotiation between the buyers and owners (11.67\%), buyers/traders $(5.83 \%)$ and sometimes the buyers and middlemen only set the price. Regarding sources of market information, as reported by the respondents $(37.5 \%),(29.17 \%),(29.17 \%),(3.33 \%)$ and $(0.83 \%)$ get market information from middlemen, other farmers, multiple response, market visit and media respectively (Table 5). As it is mentioned above the option to obtain market information legally from the government office or media is insignificant as a result the producers susceptible for bargaining and obliged to sell their animals at less price which reduce profit.

Table 5. Sources of market information and market price determination

\begin{tabular}{|c|c|c|c|c|c|}
\hline \multicolumn{6}{|c|}{$\mathrm{N}=120$} \\
\hline \multicolumn{3}{|c|}{ Sources of market information } & \multicolumn{3}{|c|}{ Price determination } \\
\hline Variables & Fre. & $\%$ & Variables & Fre. & $\%$ \\
\hline Middlemen & 45 & 37.5 & Farmers/owners & 54 & 45 \\
\hline Market visit & 4 & 3.33 & Middlemen/brokers & 41 & 34.17 \\
\hline Government media & 1 & 0.83 & Buyers & 7 & 5.83 \\
\hline Other farmers & 35 & 29.17 & Owner and buyer & 14 & 11.67 \\
\hline Multiple response & 35 & 29.17 & Middlemen and buyers & 4 & 3.33 \\
\hline Total & 120 & 100 & & 120 & 100 \\
\hline
\end{tabular}

Note. Multiple response $=$ other farmers, middlemen and market visit.

\subsection{Major Constraints of Beef Cattle Fattening}

Among the many factors that influence beef cattle production in study area, feed shortage and marketing of fattened animals were a major constraints reported by the farmers. In the study areas, seasonal variations in feed quantity and quality and the high price of industrial supplementary feed and the activities of illegal market intermediaries are the main restriction to beef animal production.

\subsubsection{Feed Constraint}

According to the findings of the present study, the most available feeds in the area were crop residues mainly sorghum stover and industrial byproducts (concentrates) with expensive purchasing prices, and there were no other green feeds during dry season. Most of the interviewed farmers reported, they have shortage of animal feeds, special during the dry season. This finding is in line with the issue reported by Tessema et al. (2003) that stated about seasonal variations in feed quality and quantity are the main limitation to animal production and cause fluctuation in productivity throughout the year, particularly in the dry seasons during which feed is limited. They also reported the high prices of agro-industrial concentrate feeds. This might be due to the lack of feed processing factories and suppliers in the area. Hence, the problems mentioned above regarding animal feed was highly affects the production and performances of the fattening animals, and livelihood of the farmers. According to most of the farmers report, there is almost no production practice of cultivation of improved forages in the area. The reason why the farmers failed to practice improved forage production as it is indicated in Table 6 were lack of land (44.1\%), lack of forage seed (25\%), lack of knowledge about forage crops (15.83\%) and combination of the above problems $(15 \%)$ were the problems reported by the farmers. 
Table 6. Practices of improved forage production and reasons for not forage production

\begin{tabular}{|c|c|c|c|c|c|}
\hline \multicolumn{6}{|c|}{$\mathrm{N}=120$} \\
\hline \multicolumn{3}{|c|}{ Improved forage production } & \multicolumn{3}{|c|}{ Reasons for no improved forage production } \\
\hline Variables & Fre. & $\%$ & Variables & Fre. & $\%$ \\
\hline Practices forage production & 6 & 5 & Lack of forage seed & 30 & 25 \\
\hline No forage production & 102 & 85 & Land Shortage & 53 & 44.17 \\
\hline Inadequate forage production & 12 & 10 & Inadequate knowledge & 19 & 15.83 \\
\hline Enough forage production & - & - & Multiple response & 18 & 15 \\
\hline Total & 120 & 100 & & 120 & 100 \\
\hline
\end{tabular}

Note. Fre. Frequency, Multiple response $=$ lack of land, lack of forage seed and information.

\subsubsection{Market Constraint}

As market constraints considered in the study area, the farmers reported that beef cattle marketing was highly influenced and constrained by the problems created by brokers during market time (Table 7). The brokers influence the market special by limiting the owners' rights to decide the price of his own cattle and affecting the processes of negotiation between the seller and buyers (Table 5). Most respondents frequently mentioned problems related to brokers activities in the market as the first ranked constraint followed by seasonality of market price variation as the second major problem (Table 7).

Table 7. Beef cattle marketing constraints in percent

\begin{tabular}{lll}
\hline \multirow{2}{*}{ Beef cattle marketing constraints } & \multicolumn{2}{c}{$\mathrm{N}=120$} \\
\cline { 2 - 3 } & Fre. & $\%$ \\
\hline Low market price & 1 & 0.83 \\
Brokers/middlemen & 93 & 77.5 \\
Seasonality of market price variation & 17 & 14.17 \\
Multiple response & 9 & 7.5 \\
Total & 120 & 100 \\
\hline
\end{tabular}

Note. Multiple response $=$ Low market price, Brokers and Seasonality of market price variation .

Most of cattle owner has almost no privacy to sell cattle without the influence of brokers. There is locally adopted Amharic word called 'teyizewal' which means, if one broker comes and see fattened cattle of the owner, other brokers may not come since the cattle of this owner already hold by the former broker, such process locally called 'teyizewal or qabameera in afaan orommo'. Sometimes brokers collect better benefits than the cattle fattener without any reasonable reason as the farmers reported. Moreover, if the brokers are not satisfied with the benefit they try to force the purchaser to breach the negotiation and finally, the cattle fatteners forced to return back the proposed cattle to sell. Therefore, such condition results in additional management cost and discouragement for cattle fatteners. This result is similar to that of Ahmed et al. (2016) which explained that the negative influence and interference of the broker in the market and their better collection of benefits than the cattle fattener with an hour. On the other hand, problems reported as the result of seasonality of market price variation is also not undermined.

\section{Conclusion}

In conclusion, this survey study provides some vital information to better understand of cattle fattening, potentials and constraints of beef cattle production in the area. It is found that there is significant difference $(\mathrm{p}<$ 0.001 ) between the highland and midland farmer groups regarding length of fattening. There is also significant difference regarding the number of fattening cycle per year $(\mathrm{p}<0.01)$ and number of fattening animals per cycle $(p<0.05)$ between the highland and midland farmer groups. Green feeds from maize and sorghum origin which includes thinning contributes a major role as livestock feed during wet season and crop residues (mainly maize and sorghum stover) are the dominant feed resources in dry season. Additionally, industrial by product mainly wheat bran which is locally known as frushika is readily available on local market and widely used by all farmers to supplement their animals. Feed shortage and marketing of fattened animals were major constraints reported by the farmers. In the study area most cattle fattener do not practice improved forage production to 
minimize the problem of feed shortage due to lack of land (44.1\%), lack of forage seed $(25 \%)$, lack of knowledge about forage crops $(15.83 \%)$ and combination of the above problems $(15 \%)$ were the problems reported by the farmers. Beef cattle marketing was highly influenced and constrained by the problems created by brokers who limit the owners' rights to decide the price of his own cattle and affecting the processes of negotiation between the seller and buyers according to the cattle fatteners report. In general speaking, most of cattle owner has almost no independency to decide their cattle price without the influence of brokers and the farmers also reported that brokers favour traders during negotiation between the owners and traders for price determination. As a result, they complain the involvement of the brokers as a cause for reduction of their profit that would be obtained from fattening of beef cattle. Well experienced and motivated nature of the farmers, traditional cattle fattening practices associated with handling culture and attributes of the experienced indigenous knowledge of the farmers and the current escalating demand for livestock and livestock product in the study area is considered as opportunities to enhance the sector. However, the sector is influenced by different constraints include the inadequate feed availability, less quality of crop residues, high price of industrial by product feeds and poorly controlled marketing systems. Therefore, strategies need to be developed in order to practice cultivation of potential forages and different legumes and the cattle marketing system should be controlled and facilitated by governmental bodies.

\section{References}

Abdi, E., Kemal, K., Yassin, E., \& Muleta, D. (2013). Cattle Production in West Hararghe: An Opportunity and Constraints Assessments in Darolabu, Odabultum, Gemechis and Chiro Districts, Oromia Regional State, Ethiop. International Journal of Livestock Production Research, 1(1), 7.

Ahmed, K., Tamir, B., \& Mengistu, A. (2016). Constraints, Opportunities and Challenges of Cattle Fattening Practices in Urban and Peri-Urban Kebeles of Dessie Town, Ethiopia. Journal of Fisheries \& Livestock Production.

Asfaw, N., Shahidur, R., \& Berhanu, G. (2011). Livestock Production and Marketing. Development Strategy and Governance Division, International Food Policy Research Institute, Ethiopia Strategy Support Program II, Ethiopia.

Ayele, S., Assegid, Workalemahu, M. A. Jabbar, M. M., \& Belachew, H. (2003). Livestock marketing in Ethiopia: A review of structure, performance and development initiatives. Socioeconomics and Policy Research, Working Paper 52. ILRI (International Livestock Research Institute), Nairobi, Kenya.

Bezahegn, A. (2014). Small Scale Beef Cattle Fattening Practices, Onfarm Performance Evaluation And Opportunities For Market Orientation In Western Hararghe Zone, Chiro District (M.Sc. Thesis, Haramaya University, Ethiopia).

CSA (Central Statistical Authority). (2011/12). Agricultural sample survey 2011/12 volume ii report on livestock and livestock characteristics.

FAO (Food and Agriculture Organization of the United Nations). (2015). Analysis of incentives for live cattle in Ethiopia or the time period 2005-2012.2015.

Fekadu, A., \& Alemu, Y. (2000). The feed resource base and feeding management of the traditional draught oxen fattening practice by smallholder farmers in the eastern Hararghe highlands. Livestock production and the environment-Implications for sustainable livelihoods (pp. 179-188). Proceedings of the $7^{\text {th }}$ annual conference of the Ethiopian Society of Animal Production (ESAP) held in Addis Ababa, Ethiopia.

Musa, L. M. A., Peters, K. J., \& Ahmed, M. K. A. (2006). On farm characterization of Butana and Kenana cattle breed production systems in Sudan. Livestock Research for Rural Development, 18(12).

SAS. (2002). Statistical Analysis System version 9.0. SAS Institute Inc., Cary, NC, USA.

Shapiro, B. I., Gebru, G., Desta, S., Negassa, A., Nigussie, K., Aboset, G., \& Mechal, H. (2015). Ethiopia livestock master plan. ILRI Project Report. Nairobi, Kenya: International Livestock Research Institute.

Tessema, Z., Aklilu, A., \& Ameha, S. (2003). Assessment of the livestock production system, available feed resources and marketing situation in Belesa Woreda: A case study in drought prone areas of Amhara Region.

Tsegaye, T., \& Mengistu, U. (2013). Assessment of commercial feedlot finishing practices at eastern Shoa, Ethiopia. Open Journal of Animal Sciences, 3(4), 273-280. https://doi.org/10.4236/ojas.2013.34041 
WHZFEDO (Hararghe Zone Finance and Economic Development Office). (2016). Annual Report. Chiro, Ethiopia.

WHZLFDO (West Hararghe Zone Livestock and Fisheries Development Office). (2018). Annual report. Chiro, Ethiopia.

Yacob, A., \& Catley, A. (2010). Livestock Exports from Pastoralist Areas: An Analysis of Benefits by Wealth Group and Policy Implications (p. 52). IGAD/LPI Working Paper.

\section{Copyrights}

Copyright for this article is retained by the author(s), with first publication rights granted to the journal.

This is an open-access article distributed under the terms and conditions of the Creative Commons Attribution license (http://creativecommons.org/licenses/by/4.0/). 